\title{
Marulda Bitkisel Özellikler, Bazı Kalite Özellikleri ve Elementler Arasındaki İlişkilerin Belirlenmesi
}

\author{
Beyhan Kibar ${ }^{*}$ \\ Bolu Abant İzzet Baysal Üniversitesi, Ziraat ve Doğa Bilimleri Fakültesi, Bahçe Bitkileri Bölümü, Bolu
}

\section{Anahtar kelimeler:}

Lactuca sativa L. var. crispa, korelasyon, bitkisel özellikler, kalite özellikleri, elementler

\begin{abstract}
Özet. Bu çalışma, farklı oranlarda vermikompost uygulanarak yetiştirilen marulda bitkisel özellikler, bazı kalite özellikleri ve besin elementleri arasındaki ilişkileri belirlemek amacıyla yapılmıştır. Araştırma, 2017 yılı sonbahar yetiştirme döneminde Karabük ili'nde ısıtmasız plastik serada yürütülmüş ve Maritima çeşidi kullanılmıştır. Çalışmada 19 adet bitkisel ve kalite ile ilgili özellik ile 21 adet element incelenmiştir. Incelenen özellikler arasındaki ilişkiler korelasyon analizi ile değerlendirilmiştir. İncelenen özelliklere ait minimum ve maksimum değerler, ortalamalar, standart hatalar, standart sapmalar ve varyasyon katsayıları belirlenmiştir. Farklı gübre uygulamalarının kullanıldığı marulda; bitki boyu 16.0030.00 cm, bitki yaş ağırlığı 133.80-320.90 g, pazarlanabilir yaprak sayısı 18-36, klorofil miktarı 13.1029.30 spad, azot içeriği \%4.29-6.98, fosfor içeriği 2211-3711 mg kg-1 ve potasyum içeriği 17129-25354 $\mathrm{mg} \mathrm{kg}^{-1}$ arasında değişiklik göstermiştir. Çalışmada vermikompost uygulamalarının marulda bitki gelişimi, kalite ve bitki besin elementi içeriği üzerine olumlu etkilerinin olduğu saptanmıştır. Korelasyon analizinin sonucunda, yaprak boyu ile yaprak eni arasında $\left(r=0.827^{\star *}\right)$ ve kuru madde oranı ile suda çözünebilir kuru madde miktarı arasında $\left(r=0.802^{\star}\right)$ önemli ve oldukça yüksek pozitif ilişkiler belirlenmiştir. Ayrıca, en önemli verim parametresi olan bitki yaş ağırlığı ile bitki kuru ağırlığı, yaprak boyu, bitki boyu ve yaprak eni arasında önemli ve pozitif korelasyonlar bulunmuştur. Elementler arasındaki ilişkiler incelendiğinde, en yüksek pozitif önemli korelasyon demir ile krom $\left(r=0.822^{\star \star *}\right)$ arasında tespit edilmiştir. Buna ilave olarak, demir ile mangan, kalsiyum ve alüminyum arasında; sodyum ile magnezyum ve potasyum arasında; nikel ile alüminyum arasında ve mangan ile kalsiyum arasında önemli ve oldukça yüksek pozitif korelasyonlar belirlenmiştir. Sonuç olarak, marul ıslah programlarında yapılacak seleksiyonlarda analiz sonuçlarının dikkate alınması gerektiği söylenebilir.
\end{abstract}

\section{Determination of the Interrelationships among Plant Properties, Some Quality Properties and Elements in Lettuce}

\section{Keywords: \\ Lactuca sativa L. var. crispa, correlation, plant properties, quality properties, elements}

\begin{abstract}
This study was conducted to determine the interrelationships among plant properties, some quality properties and elements in lettuce grown by applying vermicompost in different proportions. The experiment was carried out in the non-heated plastic greenhouse in Karabük province during the autumn growing season in 2017 and Maritima variety was used in the study. In this study, 19 properties related to plant and quality and 21 elements were examined. The interrelationships among the examined properties were evaluated by correlation analysis. Minimum and maximum values, means, standard errors, standard deviations and variation coefficients belonging to the examined properties were determined. The plant height, plant wet weight, number of marketable leaves, chlorophyll content, nitrogen content, phosphorus content and potassium content in lettuce used different fertilizer applications ranged from 16.00 to $30.00 \mathrm{~cm}, 133.80$ to $320.90 \mathrm{~g}, 18$ to $36,13.10$ to $29.30 \mathrm{spad}, 4.29$ to $6.98 \%, 2211$ to $3711 \mathrm{mg} \mathrm{kg}^{-1}$ and 17129 to $25354 \mathrm{mg} \mathrm{kg}^{-1}$, respectively. In the study, it was determined that vermicompost applications have positive effects on plant growth, quality and plant nutrient content in lettuce. As a result of the correlation analysis, significant and quite high positive relationships were determined between leaf length and leaf width $\left(r=0.827^{* *}\right)$, and between dry matter content and water soluble dry matter amount $(r=0.802 *)$. The significant and positive correlations were also found between plant wet weight which is the most important yield parameter and plant dry weight, leaf length, plant height and leaf width. When the relationships among the elements were examined, the highest positive significant correlation was detected between iron and chromium $\left(r=0.822{ }^{* *}\right)$. In addition, significant and quite high positive correlations were determined between iron and manganese, calcium and aluminum; between sodium and magnesium and potassium; between nickel and aluminum; between manganese and calcium. As a result, it can be said that analysis results should be taken into consideration for the selections in lettuce breeding programs.
\end{abstract}




\section{GíRiş}

Marul (Lactuca sativa L.), Compositae (Asteraceae) familyasının Lactuca cinsine bağlı tek yıllık bir serin iklim sebzesidir. Marul dünyada en çok yaprakları tüketilen sebzeler arasında yer almaktadır (Eşiyok 2012). Dünyada uzun yıllardan beri tarımı yapılan ve severek tüketilen marul, yılın tamamında pazarlarda ve marketlerde bulunabilmektedir (Aybak 2002). Marul form zenginliği en fazla olan sebzeler arasındadır. Ülkemizin hemen hemen her yerinde açıkta veya örtü altında yetiştirilebilmektedir. Yetişme süresi 2-3 ay gibi kısa süreli olup, değişik mevsimlere uygun olarak ıslah edilmiş çeşitlerle arka arkaya bütün yıl boyunca üretim yapmak mümkündür. Marul iklim koşullarının elverişli olduğu dönemlerde açık tarla koşullarında yetiştirilebilmektedir. İklim koşullarının elverişli olmadığı kış aylarında örtü altında, yaz aylarında ise yüksek yayla kesimlerinde verim ve kalite bakımından iyi sonuçlar alınmaktadır (Eşiyok 2012). Genellikle taze olarak tüketilen ve insan beslenmesinde önemli bir yere sahip olan marul önemli bir vitamin ve mineral madde kaynağıdır (Günay 2005). Ülkemizde 2017 yılı verilerine göre göbekli marul üretimi 223.449 ton, kıvırcık marul üretimi 185.070 ton ve aysberg marul üretimi 81.904 ton olmak üzere toplam marul üretimi 490.423 ton olarak tespit edilmiştir (TÜik 2018).

Marul organik maddeyi oldukça sevmektedir. Marul organik maddece zengin topraklarda hızlı gelişmekte ve kısa sürede hasat olgunluğuna gelmektedir (Vural ve ark., 2000). Marul gübrelemeye özellikle de azotlu gübrelemeye oldukça hassas bir tür olup gübreleme diğer şartlar eşit olduğunda verim ve kaliteyi etkileyen en önemli faktördür. Bununla birlikte, aşırı ve bilinçsiz kullanılan azotlu kimyasal gübreler bitki bünyesinde insan sağlığına zararlı olan nitrat birikimini artırmaktadır (Şensoy ve ark., 1996). Marul özellikle nitrat birikiminin en fazla olduğu sebze türlerinden biridir. Taze ağırlığında 621-12336 mg kg1 nitrat bulunabilmektedir (Santamaria 2006). İnorganik gübrelemenin organik gübrelemeye göre marul ve salatalarda üç kat daha fazla nitrat birikimine neden olduğu bildirilmiştir (Özgen ve ark., 2011). Ayrıca, organik gübrelerin kullanımı ile mikroorganizma faaliyetleri artırılarak toprağın fiziksel ve kimyasal yapısı iyileştirilebilmektedir (Özer 2016). Bu nedenle, marul yetiştiriciliğinde kimyasal gübrelerin yanında organik gübrelerin kullanımının yaygınlaştırılması gerekmektedir.

Organik gübreler arasında son yıllarda üretimi ve kullanımı gittikçe artan vermikompost (solucan gübresi) organik atıkların solucanlar tarafından sindirilmeleri sırasında kompostlaştırılması sonucunda elde edilen yüksek ekonomik değere sahip organik bir üründür (Garg and Gupta 2009; Erşahin 2010). Dolayısıyla vermikompost organik atıkların kullanımına yani onların geri dönüşümüne katkısı olan bir gübre çeşididir (Bellitürk and Görres 2012). Ayrıca, vermikest, kest veya biohumus olarak da adlandırılmaktadır (Edwards and Bohlen 1996; Şimşek Erşahin 2007). Vermikompost; çok yüksek gözeneklilik, havalandırma, drenaj, su tutma kapasitesi ve mikrobiyal aktiviteye sahiptir (Garg and Gupta 2009; Boran 2015). Vermikompost bitki besin elementleri, faydalı toprak mikroorganizmaları, çeşitli enzimler, humus, organik madde ve büyüme hormonları bakımından oldukça zengindir (Edwards and Bohlen 1996; Özkan ve ark., 2016). Vermikompost hem organik hem de konvansiyonel olarak yapılan tarımsal üretimde organik gübre ve toprak düzenleyicisi olarak geniş bir kullanım alanına sahiptir. Genellikle vermikompostun toprağa uygulanması sonucunda bitki gelişiminin ve toprak özelliklerinin önemli oranda ve olumlu yönde etkilendiği bilinmektedir. Vermikompost uygulaması ile birçok sebze türünde bitki gelişimi, verim, kalite ve besin elementi içeriklerinin arttığı belirlenmiştir (Sunaryo 2010; Joshi and Vig 2010; Jadhav et al., 2014; Jahan et al., 2014; Degwale 2016; Durak et al., 2017; Köksal ve ark., 2017; Adiloğlu et al., 2018). Ülkemizde sebze yetiştiriciliğinde vermikompost gübresi kullanımı, son yıllarda giderek popülaritesi artan bir tarımsal faaliyettir ve hızla yaygınlaşmaktadır.

Özellikler arasındaki ilişkilerin belirlenmesinde korelasyon katsayısı yaygın olarak kullanılmaktadır. Özellikle ıslah çalışmalarının ana amacı verimi ve kaliteyi arttırmaktır. Verim; bu özellik üzerinde pozitif veya negatif etkilere sahip birçok bileşen tarafından belirlenen kompleks bir karakterdir. Korelasyon katsayısı analizi, çeşitli özellikler arasındaki karşılıklı ilişkiyi ölçer, verim ve kalitede iyileşme sağlayan uygun seleksiyon kriterlerinin belirlenmesine yardımcı olur. Verim ve kalite üzerinde en büyük etkiye sahip olanlara daha fazla dikkat çekmek için çeşitli bileşenlerin her birinin katkısını incelemek önemlidir (MarjanovicJeromela et al., 2007). Islah çalışmalarında başarıya ulaşabilmek için, önce ıslah edilecek karakterler arasındaki karşılıklı ilişkiler, verimle yakından ilişkili olan karakterler ve bunların birbirleri üzerindeki karşılıklı etkileri çok iyi bilinmelidir. Bitkisel özelliklerin verime etkilerinin ne ölçüde ve nasıl olduğunun bilinmesi, ıslah çalışmalarında zamandan ve iş 
gücünden tasarruf sağlayacaktır. Bu nedenle, sebze türlerinde önemli özellikler arasındaki karşlıklı ilişkilerin bilinmesi ıslah programlarında büyük önem taşımaktadır.

Tüm bitkilerde olduğu gibi marulda da verim ve kalite yalnızca kullanılan çeşide, ekolojik faktörlere, kültürel uygulamalara bağlı değil; aynı zamanda verim ve kaliteyi oluşturan unsurların birbirleriyle olan etkileşimlerine de bağlıdır. Marulda verim ve çeşitli özellikler arasındaki karşııklı ilişkiler, daha önce birçok araştırmacı tarafından korelasyon analizi kullanılarak incelenmiştir (Çakmak 2011; Öztürk 2011; Hınıslı 2014; Smolen et al., 2015; Thakur et al., 2016; Hossain and Ryu 2017). Verim ve verime katkıda bulunan özellikler doğada kantitatif olup, çevresel ve diğer faktörlerden güçlü bir şekilde etkilenmektedir. Bu nedenle, elde edilen sonuçlar çevresel koşullara, deneme materyallerine ve denemelerin özelliklerine göre farklılık gösterebilmektedir.

Bu çalışmada, Karabük koşullarında farklı oranlarda vermikompost uygulanarak yetiştirilen marulda bitkisel özellikler, bazı kalite özellikleri ve besin elementleri arasındaki ilişkilerin korelasyon analizi ile belirlenmesi amaçlanmıştır.

\section{MATERYAL VE METOT}

Araştırma, 2017 yılı sonbahar yetiştirme döneminde Karabük ili'nde ısıtmasız plastik serada yürütülmüştür. Araştırmada bitkisel materyal olarak Maritima kıvırcık marul (Lactuca sativa L. var. crispa) çeşidi kullanılmıştır. Denemede toprak materyali olarak Karabük'te çiftçi bahçesinden alınan arazi toprağı kullanılmıştır. Denemede kullanılan vermikompost gübresi özel bir firmadan temin edilmiştir. Çalışmada kullanılan toprak ve vermikompostun bazı fiziksel ve kimyasal özellikleri deneme öncesinde yapılan analizler ile belirlenmiştir. Çalışmada kullanılan toprak killi-tınlı bir tekstüre sahip olup, pH'sı 7.4, kireç oranı \%13.16, elektriksel iletkenliği (EC) $0.67 \mathrm{dS} \mathrm{m}^{-1}$, organik madde oranı \%2.73 ve tuz miktarı \%0.027 olup tuzluluk sorunu yoktur. Ayrıca toprağın azot miktarı \%0.16, fosfor miktarı 7.7 $\mathrm{mg} \mathrm{kg}{ }^{-1}$, potasyum miktarı $385 \mathrm{mg} \mathrm{kg}^{-1}$ olarak belirlenmiştir. Çalışmada kullanılan vermikompost gübresinin ise $\mathrm{pH}^{\prime}$ sı 6.9, elektriksel iletkenliği (EC) 3.7 dS $\mathrm{m}^{-1}$, organik madde oranı \%20, azot miktarı \%1.2, fosfor miktarı \%1.09 ve potasyum miktarı \%6.51 olarak tespit edilmiştir.

Fide yetiştiriciliği plastik serada torf ve perlit karışımı (3:1) ile doldurulmuş viyollerde yapılmıştır. Tohum ekiminden yaklaşık 30-35 gün sonra fideler dikime hazır hale gelmiştir. Çalışmada plastik saksılar (26 x $24 \times 17 \mathrm{~cm}$ boyutlarında) kullanılmıştır. Her bir saksı toprak, vermikompost veya mineral gübrenin farklı dozları ile hazırlanan yetiştirme ortamı ile $5 \mathrm{~kg}$ olacak şekilde doldurulmuştur. Ortamlar ağırlık esasına göre (w/w) yüzde oranlar şeklinde düzenlenmiş olup toplam 6 farklı uygulama ele alınmıştır. Çalışmada ele alınan uygulamalar Çizelge 1'de gösterilmektedir.

Çizelge 1. Çalışmada ele alınan uygulamalar ve içerikleri.

Table 1. The applications used in the study and their contents.

\begin{tabular}{ll}
\hline Uygulama & içerik (w/w) \\
\hline 1 & \%100 Toprak + \%0 Vermikompost (Kontrol) \\
2 & \%97.5 Toprak + \%2.5 Vermikompost \\
3 & \%95 Toprak + \%5 Vermikompost \\
4 & \%90 Toprak + \%10 Vermikompost \\
5 & \%80 Toprak + \%20 Vermikompost \\
6 & \%100 Toprak + Ticari Gübre \\
\hline
\end{tabular}

Çalışma tesadüf parselleri deneme desenine göre 3 tekerrürlü olarak kurulmuştur. Her tekerrürde 5 saksı bulundurulmuş olup her uygulamada 15 saksı olmak üzere toplam 90 saksı $(6 \times 3 \times 5)$ kullanılmış ve 90 bitki yetiştirilmiştir. Çalışmada 6 no'lu uygulamada ticari gübre olarak amonyum sülfat, triple süper fosfat ve potasyum sülfat gübreleri $15 \mathrm{~kg} \mathrm{~N} \mathrm{da}^{-1}, 10 \mathrm{~kg} \mathrm{P}_{2} \mathrm{O}_{5} \mathrm{da}$ ${ }^{1}$ ve $15 \mathrm{~kg} \mathrm{~K}_{2} \mathrm{O}$ da $^{-1}$ hesabıyla uygulanmıştır. Kullanılan fosforlu ve potasyumlu gübreler ile azotlu gübrenin yarısı dikimle birlikte, azotlu gübrenin diğer yarısı ise dikimden 2 hafta sonra verilmiştir. Kontrol uygulamasına herhangi bir gübre ilavesi yapılmamıştır. Fideler 4-5 yapraklı dönemde saksılara dikilmiştir. Fide dikiminden hemen sonra can suyu verilmiştir. Fide dikiminden itibaren; hava sıcaklığı ve yetiştirme ortamındaki su durumu dikkate alınarak, intiyaç duyulduğunda sulama yapılmıştır. Hasada kadar gerekli tüm kültürel işlemler düzenli olarak uygulanmıştır (Vural ve ark., 2000). Deneme süresince herhangi bir bitki koruma ürünü kullanılmamıştır. Hasat büyüklügüne ulaşan bitkilerde dikimden 53 gün sonra hasat gerçekleştirilmiştir. Bitkiler topraktan sökülerek hasat edilmiştir. Bitkiler ölçüm ve tartım işlemleri için Bolu Abant İzzet Baysal Üniversitesi Ziraat ve Doğa Bilimleri Fakültesi Bahçe Bitkileri laboratuvarına getirilmiştir. Çalışmada bitki boyu $(\mathrm{cm})$, bitki eni $(\mathrm{cm})$, bitki yaş ağırlığı ( $\mathrm{g}$ bitki $\left.{ }^{-1}\right)$, bitki kuru ağırlığı (g bitki $\left.{ }^{-1}\right)$, kök uzunluğu $(\mathrm{cm})$, kök boğazı çapı $(\mathrm{mm})$, kök yaş ağırlığı (g bitki $\left.{ }^{-1}\right)$, kök kuru ağırı̆̆ı (g bitki $\left.^{-1}\right)$, yaprak boyu $(\mathrm{cm})$, yaprak eni $(\mathrm{cm})$, pazarlanabilir yaprak sayısı (adet bitki ${ }^{-1}$ ), kuru madde oranı (\%), pH, suda çözünebilir kuru madde miktarı (SÇKM) (\%), klorofil miktarı (SPAD), nitrat miktarı (mg $\left.\mathrm{kg}^{-1}\right)$, yaprak rengi $\left(L^{*}, C^{*}\right.$ ve $\left.h^{*}\right)$ ve element $(A l, A s, B$, 
$\mathrm{Ca}, \mathrm{Cd}, \mathrm{Co}, \mathrm{Cr}, \mathrm{Cu}, \mathrm{Fe}, \mathrm{K}, \mathrm{Mg}, \mathrm{Mn}, \mathrm{N}, \mathrm{Na}, \mathrm{Ni}, \mathrm{P}, \mathrm{Pb}, \mathrm{S}, \mathrm{Se}$, $\mathrm{Sn}$ ve $\mathrm{Zn}$ ) içerikleri ( $\mathrm{mg} \mathrm{kg}^{-1}$ veya \%) belirlenmiştir. Çalışmada bitki boyu, bitki eni, kök uzunluğu, yaprak boyu ve yaprak eni cetvel yardımıyla ölçülerek; bitki yaş ağırlığı, bitki kuru ağırlığı, kök yaş ağırlığı ve kök kuru ağırlı̆ı̆ hassas terazide tartılarak; kök boğazı çapı dijital kumpasla ölçülerek; kuru madde oranı Kılıç ve ark. (1991)'e göre; yapraklardan elde edilen suların pH'ları pH metre ile; suda çözünebilir kuru madde miktarı el refraktometresi ile; pazarlanabilir yaprak sayısı yenilebilir özellikte olan pazarlanabilir yapraklar sayılarak; yaprak rengi renk ölçer cihazı ile; klorofil miktarı klorofil ölçer ile; nitrat ve P miktarı UV-Visible Spektrofotometre ile; N ve S içeriği Elemental Analizör CHNS-O kullanılarak; diğer element içerikleri Indüktif Eşleşmiş Plazma Kütle Spektroskopisi (ICP-MS) ile belirlenmiştir.

Deneme süresince sera içi sıcaklık ve nispi nem değerleri sıcaklık ve nem kayıt cihazı (ONSET HOBO Data Logger) kullanılarak kaydedilmiştir (Şekil 1).

\section{Verilerin Değerlendirilmesi}

Çalışmada incelenen özellikler arasındaki ilişkileri ortaya koymak amacıyla elde edilen veriler korelasyon analizine tabi tutulmuş ve Pearson korelasyon katsayıları (r) saptanmıştır. Korelasyon analizi için SPSS (Version 23.0) istatistik programı kullanılmıştır.

\section{BULGULAR VE TARTIŞMA}

Farklı gübre uygulamalarının kullanıldığı marulda bitkisel özellikler ve bazı kalite özelliklerine ait minimum ve maksimum değerler, ortalamalar, standart hatalar, standart sapmalar ve varyasyon katsayıları Çizelge 2'de verilmektedir. Çalışmada bitki boyu $16.0-30.0 \mathrm{~cm}$, bitki eni $20.5-36.5 \mathrm{~cm}$, bitki yaş ağırlığı 133.80-320.90 g, yaprak boyu 13.4-19.7 cm, yaprak eni $14.5-21.8 \mathrm{~cm}$, pazarlanabilir yaprak sayısı 18-36, klorofil miktarı 13.10-29.30 spad ve nitrat miktarı 674-3824 mg kg-1 arasında değişiklik göstermiştir. Ortalama değerler bitki boyu için 20.24 $\mathrm{cm}$, bitki eni için $28.11 \mathrm{~cm}$, bitki yaş ağırlı̆ı için 203.94 g, yaprak boyu için $17.19 \mathrm{~cm}$, yaprak eni için $18.06 \mathrm{~cm}$, pazarlanabilir yaprak sayısı için 23.68 , klorofil miktarı için 21.97 spad ve nitrat miktarı için $2024.74 \mathrm{mg} \mathrm{kg}^{-1}$ olarak bulunmuştur. En düşük varyasyon katsayısı pH'da (\%1.30) belirlenirken, en yüksek varyasyon katsayısı nitrat miktarında (\%42.73) tespit edilmiştir. Çalışmada bitki boyu, bitki yaş ve kuru ağırlığı, pazarlanabilir yaprak sayısı ve klorofil içeriği bakımından vermikompost uygulamalarından kontrol uygulamasına göre daha yüksek değerler elde edilmiştir. Farklı bitki özellikleri ile kalite özellikleri için farklı vermikompost uygulamaları ön plana çıkmıştır. Marulda bitkisel özellikler ve kalite özellikleri ile ilgili benzer bulgular Çakmak (2011), Çağlar (2014), Hınıslı (2014) ve Topaklı Solak (2016) tarafından bildirilmiştir.

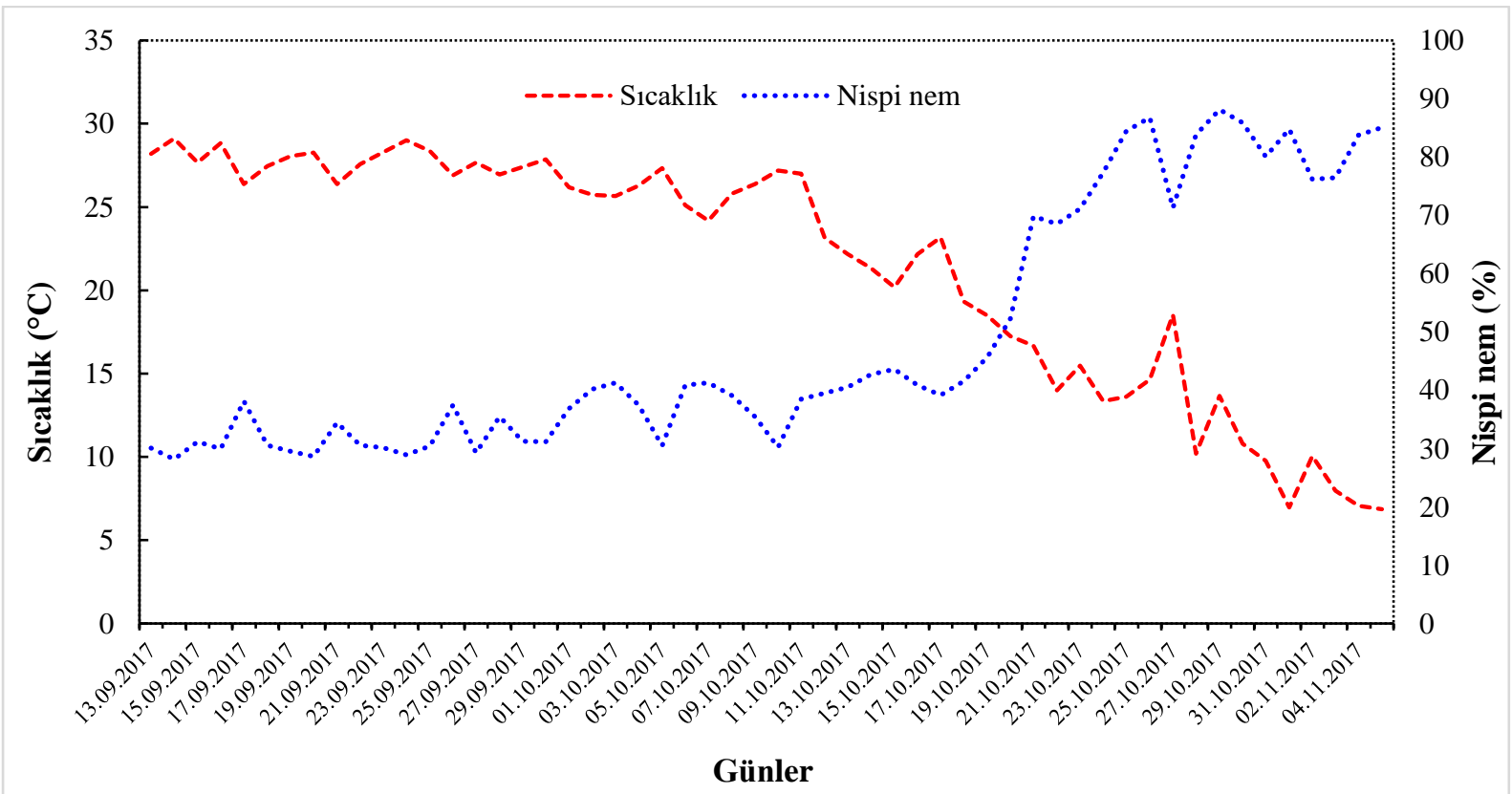

Şekil 1. Deneme süresince sera içerisinde ölçülen sıcaklık ve nispi nem değerleri.

Figure 1. Temperature and relative humidity values measured in the greenhouse during the treatment. 
Çizelge 2. Marulda bitkisel özellikler ve bazı kalite özelliklerine ait tanımlayıcı istatistikler.

Table 2. Descriptive statistics belonging to plant properties and some quality properties in lettuce.

\begin{tabular}{|c|c|c|c|c|c|}
\hline Özellikler & $\begin{array}{c}\text { Minimum ve } \\
\text { maksimum } \\
\text { değerler }\end{array}$ & $\begin{array}{c}\text { Ortalama } \pm \\
\text { Standart hata }\end{array}$ & $\begin{array}{l}\text { Standart } \\
\text { sapma }\end{array}$ & $\begin{array}{c}\text { Kareler } \\
\text { ortalaması }\end{array}$ & $\begin{array}{c}\text { Varyasyon } \\
\text { katsayısı } \\
\text { (\%) }\end{array}$ \\
\hline Bitki boyu (cm) & $16.00-30.00$ & $20.24 \pm 0.32$ & 2.72 & $13.92^{*}$ & 13.44 \\
\hline Bitki eni $(\mathrm{cm})$ & $20.50-36.50$ & $28.11 \pm 0.35$ & 2.97 & $23.99^{*}$ & 10.57 \\
\hline Bitki yaş ağırlığı (g bitki $\left.{ }^{-1}\right)$ & $133.80-320.90$ & $203.94 \pm 4.88$ & 41.44 & $3623.30^{*}$ & 20.32 \\
\hline Bitki kuru ağırlığı (g bitki-1) & $8.17-25.35$ & $15.26 \pm 0.42$ & 3.57 & $49.75^{\star \star}$ & 23.39 \\
\hline Kök uzunluğu (cm) & $9.50-17.00$ & $11.55 \pm 0.16$ & 1.34 & $3.77^{\star \star}$ & 11.56 \\
\hline Kök boğazı çapı (mm) & $9.29-24.07$ & $15.56 \pm 0.55$ & 4.63 & $20.49^{\star}$ & 29.77 \\
\hline Kök yaş ağırlığı (g bitki $\left.{ }^{-1}\right)$ & $9.00-32.65$ & $17.50 \pm 0.53$ & 4.53 & $25.21^{\text {od }}$ & 25.87 \\
\hline Kök kuru ağırlığı (g bitki-1) & $3.05-10.30$ & $4.60 \pm 0.19$ & 1.58 & $9.16^{\star *}$ & 34.31 \\
\hline Yaprak boyu (cm) & $13.40-19.70$ & $17.19 \pm 0.18$ & 1.53 & $2.86^{\circ \mathrm{d}}$ & 8.90 \\
\hline Yaprak eni $(\mathrm{cm})$ & $14.50-21.80$ & $18.06 \pm 0.18$ & 1.49 & $0.95^{\circ \mathrm{od}}$ & 8.28 \\
\hline $\begin{array}{l}\text { Pazarlanabilir yaprak sayısı } \\
\left(\text { (adet bitki }^{-1}\right)\end{array}$ & $18.00-36.00$ & $23.68 \pm 0.42$ & 3.60 & $22.11^{\text {öd }}$ & 15.21 \\
\hline Kuru madde oranı (\%) & $5.47-10.79$ & $7.40 \pm 0.14$ & 1.20 & $5.38^{\star \star}$ & 16.20 \\
\hline $\mathrm{pH}$ & $5.85-6.25$ & $6.02 \pm 0.01$ & 0.08 & $0.01^{\text {od }}$ & 1.30 \\
\hline SÇKM (\%) & $2.00-4.10$ & $2.82 \pm 0.06$ & 0.50 & $0.95^{\star \star}$ & 17.73 \\
\hline Klorofil miktarı (SPAD) & $13.10-29.30$ & $21.97 \pm 0.37$ & 3.10 & $31.41^{* *}$ & 14.11 \\
\hline Nitrat miktarı $\left(\mathrm{mg} \mathrm{kg}^{-1}\right)$ & $674.00-3824.00$ & $2024.74 \pm 101.97$ & 865.23 & $4898976.11^{\star *}$ & 42.73 \\
\hline$L^{*}$ & $39.22-60.83$ & $52.92 \pm 0.54$ & 4.55 & $6.54^{\text {öd }}$ & 8.60 \\
\hline$C^{*}$ & $21.52-37.08$ & $30.53 \pm 0.43$ & 3.61 & $15.95^{\text {öd }}$ & 11.83 \\
\hline$h^{*}$ & $79.71-116.38$ & $112.33 \pm 0.68$ & 5.74 & $22.01^{\text {odd }}$ & 5.11 \\
\hline
\end{tabular}

Farklı gübre uygulamalarının kullanıldığı marulda elementlere ait minimum ve maksimum değerler, ortalamalar, standart hatalar, standart sapmalar ve varyasyon katsayıları Çizelge 3'te verilmektedir. Çalışmada azot içeriği \%4.29-6.98, fosfor içeriği 2211$3711 \mathrm{mg} \mathrm{kg}^{-1}$, potasyum içeriği $17129-25354 \mathrm{mg} \mathrm{kg}^{-1}$, kalsiyum içeriği 3684-5456 mg kg-1, magnezyum içeriği 6525-13589 mg kg-1, demir içeriği 580.12$1025.26 \mathrm{mg} \mathrm{kg}^{-1}$, mangan içeriği $50.84-86.58 \mathrm{mg} \mathrm{kg}^{-1}$ ve çinko içeriği $41.15-122.12 \mathrm{mg} \mathrm{kg}^{-1}$ arasında değişiklik göstermiştir. Ortalama değerler azot içeriği için \%5.99, fosfor içeriği için $2775.43 \mathrm{mg} \mathrm{kg}^{-1}$, potasyum içeriği için $21215.48 \mathrm{mg} \mathrm{kg}^{-1}$, kalsiyum içeriği için $4387.11 \mathrm{mg} \mathrm{kg}^{-1}$, magnezyum içeriği için $9374.57 \mathrm{mg} \mathrm{kg}^{-1}$, demir içeriği için $793.93 \mathrm{mg} \mathrm{kg}^{-1}$, mangan içeriği için $65.45 \mathrm{mg} \mathrm{kg}^{-1}$ ve çinko içeriği için $67.20 \mathrm{mg} \mathrm{kg}^{-1}$ olarak bulunmuştur. En düşük varyasyon katsayısı potasyum miktarında (\%10.97) belirlenirken, en yüksek varyasyon katsayısı kalay miktarında (\%39.03) tespit edilmiştir. Genel olarak vermikompost uygulamalarının marulda bitki azot, fosfor, potasyum, magnezyum, kalsiyum, sodyum, demir ve bakır içeriğini kontrole göre artırdığı belirlenmiştir. Farklı elementler için farklı vermikompost uygulamaları ön plana çıkmıştır. Marulda element içerikleri ile ilgili benzer bulgular Kesimci (2013), Hınıslı (2014), Kul (2014) ve Alas (2016) tarafından bildirilmiştir.

Çalışmada incelenen bitkisel özellikler ve bazı kalite özellikleri arasındaki ilişkiler yapılan korelasyon analizi ile ortaya konulmuş ve belirlenen korelasyon katsayıları ile istatistiki olarak önem düzeyleri Çizelge 4 'te verilmiştir. Korelasyon katsayısı ( $r)-1$ ile +1 arasında değer almaktadır. Korelasyon katsayısı +1'e yaklaştıkça iki değiş̧en arasında aynı yöndeki (pozitif) ilişki artar, dolayısıyla değişkenlerden biri artarken diğeri de artar. Korelasyon katsayısı -1'e yaklaştıkça iki değişen arasında ters yöndeki (negatif) ilişki artar, değişkenlerden biri artarken diğeri azalır. Korelasyon katsayısı 0'a yaklaştıkça iki değişken arasındaki ilişki azalır.

Korelasyon analizinin sonuçlarına göre; bazı özellikler arasında kuvvetli ilişki belirlenirken, birçok özellik arasında ilişkinin bulunmadığı tespit edilmiştir. En önemli verim parametresi olan bitki yaş ağırlığı ile 
Çizelge 3. Marulda elementlere ait tanımlayıcı istatistikler.

Table 3. Descriptive statistics belonging to elements in lettuce.

\begin{tabular}{|c|c|c|c|c|c|}
\hline Elementler & $\begin{array}{l}\text { Minimum ve } \\
\text { maksimum } \\
\text { değerler }\end{array}$ & $\begin{array}{c}\text { Ortalama } \pm \\
\text { Standart hata }\end{array}$ & $\begin{array}{c}\text { Standart } \\
\text { sapma }\end{array}$ & $\begin{array}{c}\text { Kareler } \\
\text { ortalaması }\end{array}$ & $\begin{array}{c}\text { Varyasyon } \\
\text { katsayısı } \\
\text { (\%) }\end{array}$ \\
\hline Alüminyum (Al) $\left(\mathrm{mg} \mathrm{kg}^{-1}\right)$ & $145.56-519.14$ & $354.66 \pm 14.41$ & 105.86 & $34914.79 * *$ & 29.85 \\
\hline Arsenik (As) $\left(\mathrm{mg} \mathrm{kg}^{-1}\right)$ & $0.29-0.62$ & $0.43 \pm 0.01$ & 0.09 & $0.02^{*}$ & 19.64 \\
\hline Bor (B) $\left(\mathrm{mg} \mathrm{kg}^{-1}\right)$ & $44.96-85.23$ & $60.22 \pm 1.25$ & 9.21 & $33.78^{\text {öd }}$ & 15.30 \\
\hline Kalsiyum (Ca) (mg kg-1) & $3684.00-5456.00$ & $4387.11 \pm 78.15$ & 574.29 & $737688.62^{*}$ & 13.09 \\
\hline Kadmiyum $(\mathrm{Cd})\left(\mathrm{mg} \mathrm{kg}^{-1}\right)$ & $0.32-0.75$ & $0.56 \pm 0.01$ & 0.11 & $0.03^{\star *}$ & 19.01 \\
\hline Kobalt (Co) $\left(\mathrm{mg} \mathrm{kg}^{-1}\right)$ & $0.18-0.39$ & $0.29 \pm 0.01$ & 0.06 & $0.01^{\star *}$ & 19.70 \\
\hline $\operatorname{Krom}(\mathrm{Cr})\left(\mathrm{mg} \mathrm{kg}^{-1}\right)$ & $1.09-2.96$ & $2.07 \pm 0.06$ & 0.44 & $0.38^{* *}$ & 21.36 \\
\hline Bakır (Cu) (mg kg $\left.{ }^{-1}\right)$ & $13.45-28.45$ & $18.67 \pm 0.48$ & 3.56 & $54.22^{\star *}$ & 19.07 \\
\hline $\operatorname{Demir}(\mathrm{Fe})\left(\mathrm{mg} \mathrm{kg}^{-1}\right)$ & $580.12-1025.26$ & $793.93 \pm 16.77$ & 123.22 & $24897.69^{\star}$ & 15.52 \\
\hline Potasyum (K) (mg kg-1) & $17129.00-25354.00$ & $21215.48 \pm 316.62$ & 2326.69 & $22673467.59^{\star *}$ & 10.97 \\
\hline Magnezyum (Mg) $\left(\mathrm{mg} \mathrm{kg}^{-1}\right)$ & $6525.00-13589.00$ & $9374.57 \pm 222.83$ & 1637.45 & $16183100.51^{\star *}$ & 17.47 \\
\hline Mangan $(\mathrm{Mn})\left(\mathrm{mg} \mathrm{kg}^{-1}\right)$ & $50.84-86.58$ & $65.45 \pm 1.17$ & 8.56 & $136.50^{*}$ & 13.08 \\
\hline Azot (N) (\%) & $4.29-6.98$ & $5.99 \pm 0.13$ & 0.94 & $9.26^{\star *}$ & 15.69 \\
\hline Sodyum (Na) $\left(\mathrm{mg} \mathrm{kg}^{-1}\right)$ & $828.00-3112.00$ & $1930.94 \pm 102.18$ & 750.85 & $2859523.68^{\star *}$ & 38.89 \\
\hline Nikel (Ni) (mg kg-1) & $1.02-5.53$ & $3.41 \pm 0.18$ & 1.29 & $4.28^{\star *}$ & 37.85 \\
\hline Fosfor (P) (mg kg $\left.{ }^{-1}\right)$ & $2211.00-3711.00$ & $2775.43 \pm 70.87$ & 520.77 & $2827005.13^{\star *}$ & 18.76 \\
\hline Kurşun (Pb) (mg kg-1) & $1.21-3.12$ & $2.17 \pm 0.07$ & 0.49 & $0.45^{\star}$ & 22.57 \\
\hline Kükürt (S) (\%) & $3.24-6.95$ & $4.40 \pm 0.16$ & 1.20 & $14.89 * *$ & 27.36 \\
\hline Selenyum (Se) $\left(\mathrm{mg} \mathrm{kg}^{-1}\right)$ & $0.13-0.39$ & $0.24 \pm 0.01$ & 0.06 & $0.01^{\text {öd }}$ & 26.84 \\
\hline Kalay (Sn) (mg kg $\left.{ }^{-1}\right)$ & $0.59-1.74$ & $0.92 \pm 0.05$ & 0.36 & $0.20^{o ̈ d}$ & 39.03 \\
\hline Çinko (Zn) (mg kg $\left.{ }^{-1}\right)$ & $41.15-122.12$ & $67.20 \pm 3.15$ & 23.11 & 1064.09öd & 34.40 \\
\hline
\end{tabular}

*: $\mathrm{P}<0.05$ düzeyinde önemli, **: $\mathrm{P}<0.01$ düzeyinde önemli, öd: önemli değil.

bitki kuru ağırlığı $\left(r=0.677^{* *}\right)$, yaprak boyu $(r=$ $\left.0.669^{* *}\right)$, bitki boyu $\left(r=0.668^{* *}\right)$, yaprak eni $(r=$ $\left.0.646^{* *}\right)$, bitki eni $\left(r=0.463^{* *}\right)$, pazarlanabilir yaprak sayısı $(r=0.339 * *)$, kök yaş ağırlığı $\left(r=0.292^{*}\right)$ ve kök boğazı çapı $\left(r=0.291^{*}\right)$ arasında önemli ve pozitif ilişkiler belirlenmiştir. Dolayısıyla bu özelliklerdeki herhangi bir olumlu artış marulda bitki yaş ağırlığını artırmaktadır. Bununla birlikte, bitki yaş ağırlığı ile suda çözünebilir kuru madde miktarı ( $r=-0.330^{* *}$ ) ve kuru madde oranı $\left(r=-0.273^{*}\right)$ arasında önemli ve negatif korelasyonlar bulunmuş; bitki yaş ağırlığı artarken suda çözünebilir kuru madde miktarı ve kuru madde oranı azalmıştır. Bitki boyu ile bitki yaş ağırlığı ( $r=$ $\left.0.668^{* *}\right)$, yaprak boyu $\left(r=0.534^{* *}\right)$, yaprak eni $(r=$ $\left.0.475^{\star *}\right)$, bitki kuru ağırlığı $\left(r=0.321^{* *}\right)$, kök boğazı çapı $\left(r=0.310^{* *}\right)$, bitki eni $\left(r=0.282^{*}\right)$, klorofil miktarı $\left(r=0.243^{*}\right)$ ve pazarlanabilir yaprak sayısı $\left(r=0.237^{*}\right)$ arasında da önemli ve pozitif ilişkiler belirlenmiştir. Bitki boyu ile yalnızca suda çözünebilir kuru madde miktarı $\left(r=-0.317^{\star *}\right)$ arasında önemli ve negatif korelasyon gözlenmiştir. Bitki eni ile bitki yaş ağırlığı ( $r$ $\left.=0.463^{* *}\right)$, bitki kuru ağırlığı $\left(r=0.420^{* *}\right)$, yaprak boyu $\left(r=0.389^{* *}\right)$, yaprak eni $\left(r=0.369^{* *}\right)$ ve bitki boyu $(r=$ $0.282^{*}$ ) arasında önemli ve pozitif ilişkiler belirlenmiştir. Bitki eni incelenen diğer özellikler ile önemli ve negatif ilişki göstermemiştir. Bitki kuru ağırlığı ile bitki yaş ağırlığı $\left(r=0.677^{\star *}\right)$, yaprak eni $(r=$ $\left.0.445^{\star *}\right)$, yaprak boyu $\left(r=0.444^{* *}\right)$, bitki eni $(r=$ $\left.0.420^{\star *}\right), \mathrm{pH}\left(r=0.376^{\star *}\right)$, nitrat miktarı $\left(r=0.322^{* *}\right)$ ve bitki boyu $\left(r=0.321^{* *}\right)$ arasında önemli ve pozitif ilişkiler belirlenmiştir. Diğer taraftan, bitki kuru ağırlığı ile kök uzunluğu arasında önemli ve negatif ilişki ( $r=$ 0.298*) gözlenmiştir.

Kök uzunluğu yalnızca kök kuru ağırlığı ile ( $r=$ $0.257^{\star}$ ) önemli ve pozitif ilişki göstermiş olup, kuru madde oranı ( $\left.r=-0.370^{\star *}\right)$ ve bitki kuru ağırlığı ( $r=$ $0.298^{*}$ ) ile önemli ve negatif korelasyonlar sergilemiştir. Kök boğazı çapı ile yaprak eni ( $r=$ $\left.0.384^{* *}\right)$, yaprak boyu $\left(r=0.344^{* *}\right)$, bitki boyu $(r=$ $\left.0.310^{\star *}\right)$ ve bitki yaş ağırlığı $\left(r=0.291^{\star}\right)$ arasında da 
Çizelge 4. Çalışmada incelenen bitkisel özellikler ve bazı kalite özellikleri arasındaki korelasyon katsayıları.

Table 4. Correlation coefficients among plant properties and some quality properties examined in the study.

\begin{tabular}{|c|c|c|c|c|c|c|c|c|c|c|c|c|c|c|c|c|c|c|c|}
\hline Özellikler & BB & BE & BYA & BKA & KU & KBÇ & KYA & KKA & YB & YE & PYS & KMO & pH & SÇKM & KM & NM & $\mathbf{L}^{*}$ & $C^{*}$ & $\mathbf{h}^{*}$ \\
\hline BB & 1.000 & $0.282^{*}$ & $0.668^{\star \star}$ & $0.321^{\text {* }}$ & -0.071 & $0.310^{\star \star}$ & 0.046 & 0.030 & $0.534^{\star \star}$ & $0.475^{\star \star}$ & $0.237^{\star}$ & -0.195 & 0.081 & $-0.317^{\star \star}$ & $0.243^{*}$ & -0.035 & -0.049 & -0.006 & 0.032 \\
\hline BE & & 1.000 & $0.463^{\star *}$ & $0.420^{\star \star}$ & -0.138 & 0.096 & -0.108 & 0.208 & $0.389 * \star$ & $0.369^{* \star}$ & -0.002 & -0.044 & 0.194 & 0.086 & -0.101 & 0.144 & -0.097 & -0.179 & -0.056 \\
\hline BYA & & & 1.000 & $0.677^{\star \star}$ & -0.037 & $0.291^{*}$ & $0.292^{*}$ & 0.215 & $0.669^{\star \star}$ & $0.646^{* \star}$ & $0.339 * *$ & $-0.273^{*}$ & 0.147 & $-0.330^{* *}$ & -0.057 & -0.047 & -0.073 & -0.225 & 0.014 \\
\hline BKA & & & & 1.000 & $-0.298^{\star}$ & 0.098 & 0.145 & 0.080 & $0.444^{* *}$ & $0.445^{* \star}$ & 0.147 & 0.171 & $0.376^{* *}$ & 0.150 & 0.053 & $0.322^{\star \star}$ & -0.148 & -0.188 & -0.014 \\
\hline KU & & & & & 1.000 & 0.005 & 0.228 & $0.257^{*}$ & -0.130 & -0.001 & 0.007 & $-0.370^{\star *}$ & -0.232 & -0.229 & -0.195 & -0.204 & -0.095 & -0.024 & 0.073 \\
\hline KBÇ & & & & & & 1.000 & 0.142 & 0.123 & $0.344^{\star \star}$ & $0.384^{* *}$ & 0.157 & -0.199 & 0.115 & -0.137 & -0.052 & $-0.280^{\star}$ & -0.108 & -0.095 & -0.083 \\
\hline KKA & & & & & & & & 1.000 & 0.157 & 0.218 & 0.164 & -0.109 & -0.029 & 0.014 & -0.208 & -0.126 & -0.037 & -0.083 & 0.016 \\
\hline YB & & & & & & & & & 1.000 & $0.827^{* *}$ & 0.091 & -0.092 & $0.233^{*}$ & -0.221 & 0.122 & -0.121 & -0.152 & -0.147 & 0.038 \\
\hline YE & & & & & & & & & & 1.000 & 0.047 & -0.109 & 0.172 & -0.185 & 0.144 & -0.077 & -0.137 & -0.204 & -0.137 \\
\hline PYS & & & & & & & & & & & 1.000 & $-0.236^{*}$ & -0.038 & $-0.300^{*}$ & -0.065 & 0.162 & 0.058 & -0.191 & 0.136 \\
\hline КMO & & & & & & & & & & & & 1.000 & $0.290^{*}$ & $0.802^{\star \star}$ & 0.181 & 0.180 & $-0.246^{\star}$ & -0.060 & -0.039 \\
\hline pH & & & & & & & & & & & & & 1.000 & $0.307^{* *}$ & 0.059 & 0.191 & -0.159 & -0.193 & 0.159 \\
\hline KM & & & & & & & & & & & & & & & 1.000 & $0.279^{*}$ & $-0.345^{* \star}$ & -0.035 & -0.107 \\
\hline NM & & & & & & & & & & & & & & & & 1.000 & -0.085 & -0.006 & 0.048 \\
\hline $\mathrm{L}^{*}$ & & & & & & & & & & & & & & & & & 1.000 & $0.547^{\star \star}$ & 0.224 \\
\hline $\mathrm{C}^{*}$ & & & & & & & & & & & & & & & & & & 1.000 & 0.087 \\
\hline$h^{*}$ & & & & & & & & & & & & & & & & & & & 1.000 \\
\hline
\end{tabular}

*: P<0.05 düzeyinde önemli, **: P<0.01 düzeyinde önemli, BB: Bitki boyu, BE: Bitki eni, BYA: Bitki yaş ağırlığı, BKA: Bitki kuru ağırlığı, KU: Kök uzunluğu, KBÇ: Kök boğazı çapı, KYA: Kök yaş ağı̆rlı̆̆ı, KKA: Kök kuru ağırlı̆̆ı,

YB: Yaprak boyu, YE: Yaprak eni, PYS: Pazarlanabilir yaprak sayııı, KMO: Kuru madde oranı, SÇKM: Suda çözünebilir kuru madde miktarı, KM: Klorofil miktarı, NM: Nitrat miktarı, $L^{\star}$, $C^{\star}$ ve $h^{\star}$ : renk değerleri. 
önemli ve pozitif ilişkiler belirlenmiştir. Buna karşılık, kök boğazı çapı ile nitrat miktarı arasında önemli ve negatif ilişki $\left(r=-0.280^{\star}\right)$ gözlenmiştir. Kök yaş ağırlığı ile kök kuru ağırlığı $\left(r=0.448^{* *}\right)$, pazarlanabilir yaprak sayısı $\left(r=0.370^{* *}\right)$ ve bitki yaş ağırlığı $\left(r=0.292^{*}\right)$ arasında önemli ve pozitif; kök yaş ağırlığı ile suda çözünebilir kuru madde miktarı $\left(r=-0.335^{\star \star}\right)$, kuru madde oranı $\left(r=-0.280^{*}\right)$ ve $\mathrm{pH}\left(r=-0.235^{*}\right)$ arasında ise önemli ve negatif korelasyonlar belirlenmiştir. Kök kuru ağırlığı ile yalnızca kök yaş ağırlığı ve kök uzunluğu arasında önemli ve pozitif ilişkiler belirlenmiştir. Kök kuru ağırlığının incelenen diğer özellikler ile ilişkisi zayıf (önemsiz) bulunmuştur.

Çalışmada incelenen özellikler arasında en yüksek pozitif önemli korelasyon, yaprak boyu ile yaprak eni arasında $\left(r=0.827^{\star *}\right)$ belirlenmiş̧ir. Ayrıca, yaprak boyu ile bitki boyu, bitki eni, bitki yaş ağırlığı, bitki kuru ağırlığı, kök boğazı çapı ve pH arasında da önemli ve pozitif ilişkiler belirlenmiştir. Yaprak boyuna benzer şekilde, yaprak eni ile bitki boyu, bitki eni, bitki yaş ağırlığı, bitki kuru ağırlığı, kök boğazı çapı ve yaprak boyu arasında da önemli ve pozitif ilişkiler belirlenmiştir. Yaprak boyu ve yaprak eni incelenen diğer özellikler ile önemli ve negatif ilişki göstermemiştir. Pazarlanabilir yaprak sayısı ile bitki boyu, bitki yaş ağırlığı ve kök yaş ağırlığı arasında önemli ve pozitif ilişkiler saptanırken, pazarlanabilir yaprak sayısı ile suda çözünebilir kuru madde miktarı $\left(r=-0.300^{*}\right)$ ve kuru madde oranı $\left(r=-0.236^{*}\right)$ arasında ise önemli ve negatif korelasyonlar gözlenmiştir.

Çizelge 4'te görüldüğü gibi, kuru madde oranı ve suda çözünebilir kuru madde miktarı arasında oldukça yüksek pozitif ilişki $\left(r=0.802^{* *}\right)$ belirlenmiştir. Bu iki parametre arasındaki yüksek korelatif ilişki suda çözünebilir kuru madde miktarını etkileyen faktörün ağırlıklı olarak kuru madde oranı olduğunu göstermektedir. Ayrıca, kuru madde oranı ve $\mathrm{pH}$ arasında $\left(r=0.290^{*}\right)$ da önemli ve pozitif ilişki belirlenmiştir. Bununla birlikte, kuru madde oranı ile bitki yaş ağırlığı, kök uzunluğu, kök yaş ağırlığı, pazarlanabilir yaprak sayısı ve $L^{*}$ değeri arasında önemli ve negatif korelasyonlar gözlenmiştir. $\mathrm{pH}$ ile bitki kuru ağırığı, yaprak boyu, kuru madde oranı ve suda çözünebilir kuru madde miktarı arasında önemli ve pozitif korelasyonlar gözlenmiştir. pH ile yalnızca kök yaş ağırlığı arasında önemli ve negatif ilişki gözlenmiştir. Suda çözünebilir kuru madde miktarı ile kuru madde oranı ve $\mathrm{pH}$ arasında önemli ve pozitif; suda çözünebilir kuru madde miktarı ile bitki boyu, bitki yaş ağırlığı, kök yaş ağırlığı, pazarlanabilir yaprak sayısı ve $L^{*}$ değeri arasında önemli ve negatif ilişkiler saptanmıştır. Klorofil miktarı ile bitki boyu ve nitrat miktarı arasında önemli ve pozitif ilişkiler belirlenirken, klorofil miktarı ile $L^{*}$ değeri arasında önemli ve negatif bir korelasyon olduğu tespit edilmiştir. Nitrat miktarı ile bitki kuru ağırığı ve klorofil miktarı arasında önemli ve pozitif ilişkiler saptanırken, nitrat miktarı ile kök boğazı çapı arasında önemli düzeyde negatif ilişki gözlenmiştir. İncelenen renk özellikleri arasında, $L^{*}$ değeri yalnızca $C^{*}$ değeri ile önemli ve pozitif korelasyona $\left(r=0.547^{\star \star}\right)$ sahip bulunmuştur. $L^{*}$ değeri ile klorofil miktarı $\left(r=-0.345^{* *}\right)$, suda çözünebilir kuru madde miktarı $\left(r=-0.265^{\star}\right)$ ve kuru madde oranı $(r=$ $-0.246^{\star}$ ) arasında önemli ve negatif korelasyonlar gözlenmiştir. Kök uzunluğu ile kök boğazı çapı ve pazarlanabilir yaprak sayısı arasındaki ilişkiler; $C^{*}$ değeri ile bitki boyu ve nitrat miktarı arasındaki ilişkilerin yok denecek kadar düşük düzeyde olduğu görülmektedir (Çizelge 4).

Çakmak (2011) kıvırcık yapraklı salatada yaptığı çalışmada toplam baş ağırlığı ile pazarlanabilir baş ağırlığı ve verim arasında; toplam yaprak sayısı ile pazarlanabilir yaprak sayısı arasında; pazarlanabilir baş ağırlığı ile pazarlanabilir yaprak sayısı ve verim arasında; pazarlanabilir yaprak sayısı ile verim arasında pozitif ve önemli ilişkilerin olduğunu bildirmiştir. Öztürk (2011) tarafından kıvırcık yapraklı salatada yapılan çalışmada baş çapı ile bitki ağırlığı, pazarlanabilir baş ağırlığı ve pazarlanabilir verim arasında pozitif bir korelasyon belirlenirken, baş çapı ile toplam yaprak sayısı, pazarlanabilir yaprak sayısı, $\mathrm{pH}$ ve SÇKM arasında negatif bir ilişki bulunmuştur. Bitki ağırlı̆ı ile baş çapı, pazarlanabilir baş ağırlığı ve pazarlanabilir verim arasında pozitif korelasyon bulunmuştur. Diğer taraftan, bitki ağırlığı ile toplam yaprak sayısı, pH ve SÇKM arasında negatif bir korelasyon tespit edilmiştir. Toplam yaprak sayısı ile $\mathrm{pH}$ ve SÇKM arasında pozitif bir korelasyon bulunurken, toplam yaprak sayısı ile baş çapı, bitki ağırlığı, pazarlanabilir baş ağırlığı ve pazarlanabilir verim arasında negatif bir ilişki belirlenmiştir. Pazarlanabilir baş ağırlığı ile bitki boyu, baş çapı, bitki ağırlığı ve pazarlanabilir verim arasında pozitif bir korelasyon bulunurken, pazarlanabilir baş ağırlığı ile $\mathrm{pH}$ ve SÇKM arasında negatif bir korelasyon oluşmuştur. Ayrıca çalışmada $\mathrm{pH}$ ve SÇKM arasında pozitif bir korelasyon belirlenmiştir. Pazarlanabilir yaprak sayısı ile SÇKM arasında negatif bir ilişki bulunmuştur. Hossain and Ryu (2017) yaptığı çalışmada marulda verim ile bitki boyu ve yaprak sayısı arasında pozitif ve önemli korelasyonların olduğunu bildirmiştir.

Araştırmada incelenen elementler arasındaki korelasyon katsayıları ile istatistiki olarak önem düzeyleri Çizelge $5^{\prime}$ de sunulmuştur. Çizelge 5 
Çizelge 5. Çalışmada incelenen elementler arasındaki korelasyon katsayıları.

\begin{tabular}{|c|c|c|c|c|c|c|c|c|c|c|c|c|c|c|c|c|c|c|c|c|c|}
\hline Elementler & Al & As & B & $\mathrm{Ca}$ & $\mathrm{Cd}$ & Co & $\mathrm{Cr}$ & $\mathrm{Cu}$ & $\mathrm{Fe}$ & K & Mg & Mn & $N$ & $\mathrm{Na}$ & $\mathrm{Ni}$ & $\mathbf{P}$ & $\mathbf{P b}$ & $\mathbf{s}$ & Se & Sn & $\mathrm{Zn}$ \\
\hline Al & 1.000 & 0.096 & 0.227 & $0.498^{\star \star}$ & 0.193 & $0.504^{\star \star}$ & $0.652^{\star \star}$ & 0.003 & $0.725^{\star \star}$ & 0.232 & 0.110 & $0.521^{\star \star}$ & -0.261 & 0.025 & $0.761^{\star \star}$ & $0.340^{*}$ & -0.170 & $0.311^{\star}$ & $0.386^{\star \star}$ & -0.045 & $-0.276^{*}$ \\
\hline As & & 1.000 & $0.500^{\star \star}$ & $0.685^{\star \star}$ & $0.412^{* \star}$ & $0.436^{* \star}$ & 0.197 & -0.226 & $0.358^{\star \star}$ & $0.350^{* \star}$ & $0.441^{\star \star}$ & $0.544^{\star \star}$ & -0.076 & $0.349^{* *}$ & 0.067 & -0.083 & $0.512^{\star \star}$ & -0.018 & -0.169 & -0.217 & $-0.273^{*}$ \\
\hline B & & & 1.000 & $0.473^{* *}$ & $0.449^{\star *}$ & $0.449^{\star *}$ & $0.318^{\star}$ & $-0.451^{* *}$ & $0.421^{* \star}$ & $0.298^{\star}$ & -0.040 & $0.521^{* *}$ & 0.031 & -0.029 & 0.133 & 0.147 & $0.528^{\star \star}$ & 0.111 & $0.332^{\star}$ & $-0.301^{\star}$ & $-0.625^{\star \star}$ \\
\hline $\mathrm{Ca}$ & & & & 1.000 & $0.292^{\star}$ & $0.559^{\star \star}$ & $0.576^{\star \star}$ & -0.179 & $0.766^{\star \star}$ & $0.494^{\star \star}$ & $0.604^{\star \star}$ & $0.765^{\star \star}$ & -0.149 & $0.509^{\star *}$ & $0.412^{\star \star}$ & -0.148 & $0.436^{* *}$ & -0.096 & 0.100 & $-0.296^{*}$ & -0.256 \\
\hline $\mathrm{Cd}$ & & & & & 1.000 & $0.580^{\star \star}$ & 0.151 & $-0.691^{\star *}$ & $0.327^{\star}$ & $-0.326^{*}$ & $-0.334^{*}$ & $0.365^{\star *}$ & $-0.369^{\star \star}$ & $-0.319^{*}$ & $0.408^{\star *}$ & -0.014 & $0.688^{\star \star}$ & $0.459^{* *}$ & 0.205 & -0.013 & $-0.363^{\star \star}$ \\
\hline Co & & & & & & 1.000 & $0.504^{\star \star}$ & $-0.462^{\star *}$ & $0.639^{\star \star}$ & -0.009 & 0.067 & $0.647^{\star \star}$ & $-0.427^{\star \star}$ & -0.045 & $0.476^{\star \star}$ & -0.184 & $0.342^{\star}$ & $0.397^{\star \star}$ & 0.212 & -0.198 & $-0.368^{\star \star}$ \\
\hline $\mathrm{Cr}$ & & & & & & & 1.000 & 0.052 & $0.822^{\star *}$ & $0.350^{\star \star}$ & $0.441^{\star \star}$ & $0.590^{\star \star}$ & -0.074 & $0.337^{\star}$ & $0.451^{\star \star}$ & 0.208 & -0.046 & 0.221 & $0.410^{* \star}$ & 0.075 & -0.154 \\
\hline $\mathrm{Cu}$ & & & & & & & & 1.000 & -0.172 & $0.442^{\star \star}$ & $0.436^{\star \star}$ & -0.186 & $0.431^{\star \star}$ & $0.543^{* *}$ & $-0.321^{*}$ & 0.226 & $-0.633^{* *}$ & $-0.436^{* *}$ & $-0.285^{*}$ & $0.291^{\star}$ & $0.392^{\star *}$ \\
\hline $\mathrm{Fe}$ & & & & & & & & & 1.000 & $0.328^{\star}$ & $0.337^{\star}$ & $0.767^{\star \star}$ & -0.166 & 0.235 & $0.514^{\star \star}$ & 0.041 & 0.191 & 0.152 & $0.392^{\star \star}$ & -0.202 & $-0.433^{\star \star}$ \\
\hline K & & & & & & & & & & 1.000 & $0.567^{\star \star}$ & $0.470^{* \star}$ & $0.457^{\star \star}$ & $0.755^{* *}$ & -0.183 & 0.099 & 0.020 & $-0.361^{\star \star}$ & -0.132 & -0.065 & -0.089 \\
\hline Mg & & & & & & & & & & & 1.000 & $0.292^{\star}$ & 0.055 & $0.791^{\star *}$ & -0.075 & -0.082 & -0.134 & $-0.378^{\star \star}$ & -0.224 & 0.003 & 0.253 \\
\hline Mn & & & & & & & & & & & & 1.000 & -0.064 & $0.274^{\star}$ & $0.351^{\star \star}$ & -0.038 & $0.319^{\star}$ & 0.196 & $0.276^{*}$ & -0.220 & $-0.424^{\star \star}$ \\
\hline $\mathbf{N}$ & & & & & & & & & & & & & 1.000 & $0.349^{* *}$ & $-0.330^{*}$ & 0.232 & -0.110 & $-0.444^{\star \star}$ & $-0.340^{*}$ & -0.183 & -0.047 \\
\hline $\mathrm{Na}$ & & & & & & & & & & & & & & 1.000 & -0.211 & -0.214 & 0.077 & $-0.508^{\star \star}$ & $-0.334^{\star}$ & 0.109 & $0.330^{*}$ \\
\hline $\mathrm{Ni}$ & & & & & & & & & & & & & & & 1.000 & 0.214 & 0.060 & $0.461^{\star \star}$ & $0.353^{* \star}$ & -0.004 & -0.093 \\
\hline $\mathbf{P}$ & & & & & & & & & & & & & & & & 1.000 & $-0.302^{*}$ & $0.370^{\star \star}$ & 0.130 & 0.213 & -0.267 \\
\hline Pb & & & & & & & & & & & & & & & & & 1.000 & 0.099 & 0.037 & -0.101 & -0.265 \\
\hline s & & & & & & & & & & & & & & & & & & 1.000 & $0.358^{* \star}$ & $0.280^{*}$ & -0.172 \\
\hline Se & & & & & & & & & & & & & & & & & & & 1.000 & 0.104 & -0.233 \\
\hline Sn & & & & & & & & & & & & & & & & & & & & 1.000 & $0.569^{\star \star}$ \\
\hline $\mathrm{Zn}$ & & & & & & & & & & & & & & & & & & & & & 1.000 \\
\hline
\end{tabular}


incelendiğinde, bazı elementlerin birbirleri ile yüksek korelasyon içerisinde olduğu görülmektedir. Özellikle demir ile krom $\left(r=0.822^{\star *}\right)$, mangan $\left(r=0.767^{* *}\right)$, kalsiyum $\left(r=0.766^{\star *}\right)$, alüminyum $\left(r=0.725^{\star *}\right)$ ve kobalt arasında $\left(r=0.639^{* *}\right)$; kalsiyum ile demir $(r=$ $\left.0.766^{\star \star}\right)$, mangan $\left(r=0.765^{\star *}\right)$ ve arsenik $\left(r=0.685^{\star *}\right)$ arasında; sodyum ile magnezyum $\left(r=0.791^{* *}\right)$ ve potasyum $\left(r=0.755^{\star *}\right)$ arasında; mangan ile demir $(r$ $\left.=0.767^{\star *}\right)$, kalsiyum $\left(r=0.765^{* *}\right)$ ve kobalt $(r=$ $\left.0.647^{\star \star}\right)$ arasında; nikel ile alüminyum $\left(r=0.761^{* *}\right)$ arasında; kurşun ile kadmiyum arasında $\left(r=0.688^{* *}\right)$ oldukça yüksek pozitif ilişkiler belirlenmiştir. Çalışmada incelenen elementler arasında en yüksek pozitif önemli korelasyon, demir ile krom arasında $(r=$ $0.822^{* *}$ ) belirlenmiştir. Ayrıca, bu bahsedilen önemli pozitif korelasyonlara ilave olarak kalsiyum ile alüminyum, bor, kadmiyum, kobalt, krom, potasyum, magnezyum, sodyum, nikel ve kurşun arasında; demir ile arsenik, bor, kadmiyum, potasyum, magnezyum, nikel ve selenyum arasında; potasyum ile arsenik, bor, kalsiyum, krom, bakır, demir, magnezyum, mangan ve azot arasında; magnezyum ile arsenik, kalsiyum, krom, bakır, demir, potasyum ve mangan arasında; mangan ile alüminyum, arsenik, bor, kadmiyum, krom, potasyum, magnezyum, sodyum, nikel, kurşun ve selenyum arasında; azot ile bakır, potasyum ve sodyum arasında; sodyum ile arsenik, kalsiyum, krom, bakır, mangan, azot ve çinko arasında; fosfor ile alüminyum ve kükürt arasında; kükürt ile alüminyum, kadmiyum, kobalt, nikel, fosfor, selenyum ve kalay arasında; selenyum ile alüminyum, bor, krom, demir, mangan, nikel ve kükürt arasında; çinko ile bakır, sodyum ve kalay arasında; alüminyum ile kalsiyum, kobalt, mangan, fosfor, kükürt ve selenyum arasında; arsenik ile bor, kadmiyum, kobalt, demir, potasyum, magnezyum, mangan, sodyum ve kurşun arasında; bor ile arsenik, kalsiyum, kadmiyum, kobalt, krom, demir, potasyum, mangan, kurşun ve selenyum arasında; kadmiyum ile arsenik, bor, kalsiyum, kobalt, demir, mangan, nikel ve kükürt arasında; kobalt ile alüminyum, arsenik, bor, kalsiyum, kadmiyum, krom, nikel, kurşun ve kükürt arasında; krom ile bor, kalsiyum, kobalt, potasyum, magnezyum, mangan, sodyum, nikel ve selenyum arasında; bakır ile potasyum, magnezyum, azot, sodyum, kalay ve çinko arasında da önemli ve pozitif korelasyonlar belirlenmiştir. Buna karşılık; bakır ile bor, kadmiyum, kobalt, nikel, kurşun, kükürt ve selenyum arasında; çinko ile alüminyum, arsenik, bor, kadmiyum, kobalt, demir ve mangan arasında; azot ile kadmiyum, kobalt, nikel, kükürt ve selenyum arasında; fosfor ile kurşun arasında; kadmiyum ile bakır, potasyum, magnezyum, azot ve çinko arasında; kükürt ile bakır, potasyum, magnezyum, azot ve sodyum arasında; kalay ile bor ve kalsiyum arasında; selenyum ile bakır, azot ve sodyum arasında önemli ve negatif ilişkiler saptanmıştır. Elementler arasındaki en yüksek negatif önemli korelasyon, bakır ile kadmiyum arasında $\left(r=-0.691^{\star \star}\right)$ tespit edilmiştir. Belirlenen korelasyon katsayılarından bitki besin elementlerinin birbirleriyle etkileşimde bulundukları anlaşılmaktadır. Fosforun alüminyum, kükürt ve kurşun dışındaki diğer elementlerle ilişkisinin önemsiz olduğu belirlenmiştir. Bakır ve çinko diğer elementler ile en fazla negatif ilişki gösteren elementler olmuştur. Kalay ile magnezyum ve nikel; bakır ile alüminyum; potasyum ile kobalt arasındaki ilişkilerin yok denecek kadar düşük düzeyde olduğu saptanmıştır (Çizelge 5).

Hınıslı (2014) tarafından kıvırcık marulda yapılan çalışmada vermikompost uygulaması ile bitkideki çinko, kalsiyum, bakır, magnezyum ve azot içeriği arasında pozitif korelasyonlar belirlenmiştir. Buna karşılık vermikompost uygulaması ile bitkideki potasyum, fosfor, demir, mangan ve bor içeriği arasında negatif ilişkiler gözlenmiştir. Smolen et al. (2015) tarafından marulda yapılan çalışmada selenyum ile magnezyum ve demir arasında pozitif ve önemli ilişkiler saptanırken, selenyum ile fosfor ve sodyum arasında negatif ve önemli korelasyonlar gözlenmiştir. Araştırıcı ayrıca iyot ile fosfor ve sodyum arasında pozitif ve önemli korelasyonların olduğunu bildirmiştir. Thakur et al. (2016) marulda yaptıkları çalışmada verim ile baş ağırlığı arasında oldukça yüksek pozitif ve önemli bir korelasyonun olduğunu, demir ve kalsiyum arasında ise negatif ve önemli bir korelasyonun olduğunu bildirmişlerdir. Eryüksel (2016) tarafından yapılan çalışmada maydanozda N, P, K, Zn, elementleriyle vermikompost arasında pozitif yönde; $\mathrm{Ca}, \mathrm{B}$ ve $\mathrm{Mn}$ elementleriyle vermikompost arasında ise negatif yönde ilişki olduğu belirlenmiştir. Semizotunda ise $K, P, Z n$ ve $N$ elementleriyle vermikompost arasında pozitif yönde; $\mathrm{Ca}, \mathrm{B}, \mathrm{Mn}$, $\mathrm{Fe}$ ve $\mathrm{Mg}$ elementleri ile vermikompost arasında negatif yönde ilişki bulunmuştur.

\section{SONUC}

Bu çalışmada; marulda bitkisel özellikler, bazı kalite özellikleri ve besin elementleri arasındaki ilişkiler incelenmiştir. İncelenen bazı özellikler ve elementler arasında yüksek korelasyonlar gözlenmiştir. Çalışma sonucunda en önemli verim parametresi olan bitki yaş ağırlığı üzerinde bitki kuru ağırlığı, yaprak boyu, bitki boyu ve yaprak eninin oldukça önemli ve pozitif etkilere sahip olduğu belirlenmiştir. Ayrıca, yaprak boyu ile yaprak eni arasında; kuru madde oranı ve suda çözünebilir kuru madde miktarı arasında da önemli ve 
oldukça yüksek pozitif ilişkiler belirlenmiştir. Elementler arasındaki ilişkiler incelendiğinde ise özellikle demir ile krom, mangan, kalsiyum ve alüminyum arasında; sodyum ile magnezyum ve potasyum arasında; nikel ile alüminyum arasında ve mangan ile kalsiyum arasında oldukça yüksek pozitif korelasyonlar belirlenmiştir. Buna karşılık bakır ile kadmiyum arasında oldukça yüksek negatif önemli korelasyon tespit edilmiştir. Marulun önemli özelliklerinin korelasyon analizi, ıslah programlarında marul ıslahçılarının uygun seleksiyon kriterlerini belirlemelerine yardımcı olacaktır.

\section{TEŞEKKÜR}

Bu çalışma Bolu Abant İzzet Baysal Üniversitesi Bilimsel Araştırma Projeleri Koordinatörlüğü (Proje No: 2017.10.05.1194) tarafından desteklenmiştir.

\section{KAYNAKLAR}

Adiloğlu S., Eryılmaz Açıkgöz F., Solmaz Y., Çaktü E and Adiloğlu A., 2018. Effect of vermicompost on the growth and yield of lettuce plant (Lactuca sativa L. var. crispa). International Journal of Plant \& Soil Science, 21(1): 1-5.

Alas E., 2016. Bitki antifiriz ve farklı yetiştirme sistemlerinin marul yetiştiriciliğinde verim, bazı kalite özellikleri ve besin maddesi içeriğine etkisi. Yüksek Lisans Tezi, Dicle Üniversitesi Fen Bilimleri Enstitüsü, Diyarbakır.

Aybak HÇ., 2002. Salata/Marul Yetiştiriciliği. Hasad Yayıncılılık, İstanbul.

Bellitürk K and Görres JH., 2012. Balancing vermicomposting benefits with conservation of soil and ecosystems at risk of earhworm invasions. VIII. International Soil Science Congress on Land Degradataion and Challenges in Sustainable Soil Management, May 15-17, Çeşme, İzmir.

Boran D., 2015. Farklı ısıl teknikleri uygulanmış solucan gübresinin kalite parametrelerinin belirlenmesi. Yüksek Lisans Tezi, Ankara Üniversitesi Fen Bilimleri Enstitüsü, Ankara.

Çağlar S., 2014. Fındık zuruf kompostu ve çay kompostu karışımlarının kıvırcık marulda (Lactuca sativa L. var. crispa) verim ve kaliteye etkisi. Yüksek Lisans Tezi, Ordu Üniversitesi Fen Bilimleri Enstitüsü, Ordu.

Çakmak P., 2011. Farklı dikim zamanları ve organik gübrelerin topraksız tarım koşullarında kıvırcık yapraklı salata (Lactuca sativa var. crispa) yetiştiriciliğinde verim ve kalite özelliklerine etkisi. Yüksek Lisans Tezi, Gaziosmanpaşa Üniversitesi Fen Bilimleri Enstitüsü, Tokat.

Degwale A., 2016. Effect of vermicompost on growth, yield and quality of garlic (Allium sativum L.) in Enebse Sar Midir District, Northwestern Ethiopia. Journal of Natural Sciences Research, 6(3): 51-63.

Durak A., Altuntaş Ö., Kutsal iK., Işık R and Karaat FE., 2017.
The effects of vermicompost on yield and some growth parameters of lettuce. Turkish Journal of AgricultureFood Science and Technology, 5(12): 1566-1570.

Edwards CA and Bohlen PJ., 1996. Biology and Ecology of Earthworms. 3rd. Ed. Chapman and Hall, New York.

Erşahin S., 2010. Vermikompost ürünleri organik üretime ne sunabilir. Türkiye IV. Organik Tarım Sempozyumu, 28 Haziran-1 Temmuz, Erzurum.

Eryüksel S., 2016. Farklı oranlarda vermikompost uygulamasının bazı sebzelerin besin elementi içerikleri üzerine olan etkileri. Yüksek Lisans Tezi, Namık Kemal Üniversitesi Fen Bilimleri Enstitüsü, Tekirdağ.

Eşiyok D., 2012. Kışlık ve Yazlık Sebze Yetiştiriciliği. Meta Basım, Bornova/Izmir.

Garg VK and Gupta R., 2009. Vermicomposting of agroindustrial processing waste. Biotechnology for AgroIndustrial Residues Utilisation (Eds. Nigam PSN and Pandey A), Springer, Netherlands, pp. 431-456.

Günay A., 2005. Sebze Yetiştiriciliği, Cilt II. İzmir.

Hınıslı N., 2014. Vermikompost gübresinin kıvırcık bitkisinin gelişmesi üzerine etkisinin belirlenmesi ve diğer bazı organik kaynaklı gübrelerle karşılaştırılması. Yüksek Lisans Tezi, Namık Kemal Üniversitesi Fen Bilimleri Enstitüsü, Tekirdağ.

Hossain MB and Ryu KS., 2017. Effects of organic and inorganic fertilizers on lettuce (Lactuca sativa L.) and soil properties. SAARC Journal of Agriculture, 15(2): 93-102.

Jadhav PB., Patel DJ., Kireeti A., Patil NB., Dekhane SS., Harad NB and Jadhav KP., 2014. Effect of different levels of vermicompost on growth and yield of radish cv. local variety. International Journal of Information Research and Review, 1(2): 29-31.

Jahan FN., Shahjalal ATM., Paul AK., Mehraj $H$ and Jamal Uddin AFM., 2014. Efficacy of vermicompost and conventional compost on growth and yield of cauliflower. Bangladesh Research Publications Journal, 10(1): 33-38.

Joshi R and Vig AP., 2010. Effect of vermicompost on growth, yield and quality of tomato (Lycopersicum esculentum $\mathrm{L}$ ). African Journal of Basic \& Applied Sciences, 2(3-4): 117123.

Kesimci E., 2013. Sera koşullarında bitki büyümesini artırıcı rizobakterlerin marulda verim, verim unsurları ve besin elementi içeriklerine etkileri. Yüksek Lisans Tezi, Selçuk Üniversitesi Fen Bilimleri Enstitüsü, Konya.

Kılıç O., Çapur U ve Görtay Ş., 1991. Meyve ve Sebze İşleme Teknolojisi Uygulama Kılavuzu. Uludağ Üniversitesi Ziraat Fakültesi Ders Notları.

Köksal SB., Aksu G ve Altay H., 2017. Vermikompostun bazı toprak özellikleri ve pazı bitkisinde verim üzerine etkisi. Çanakkale Onsekiz Mart Üniversitesi Ziraat Fakültesi Dergisi, 5(2): 123-128. 
Kul R., 2014. Balık gübresi, mineral gübre ve kombinasonlarının marulda (Lactuca sativa L.) bitki gelişimi ve besin elementi içeriği üzerine etkisi. Yüksek Lisans Tezi, Atatürk Üniversitesi Fen Bilimleri Enstitüsü, Erzurum.

Marjanovic-Jeromela A., Marjanovic R., Mijic A., Zdunic Z., Ivanovska $S$ and Jankulovska M., 2007. Correlation and path analysis of quantitative traits in winter rapeseed $(B$. Napus L.). Agriculturae Conspectus Scientificus, 73: 1318.

Özer H., 2016. Organik domates yetiştiriciliği. Uluslararası Tarım ve Yaban Hayatı Bilimleri Dergisi, 2(1): 43-53.

Özgen Ş., Şekerci Ş ve Karabıyık T., 2011. Organik ve inorganik gübrelemenin marul ve salatalarin nitrat birikimi üzerine etkisi. VI. Türkiye Ulusal Bahçe Bitkileri Kongresi, 4-8 Ekim, Şanlıurfa.

Özkan N., Dağlıoğlu M., Ünser E ve Müftüoğlu N.M., 2016. Vermikompostun ıspanak (Spinacia oleracea L.) verimi ve bazı toprak özellikleri üzerine etkisi. Çanakkale Onsekiz Mart Üniversitesi Ziraat Fakültesi Dergisi, 4(1): 1-5.

Öztürk B., 2011. Farklı dikim zamanlarında kıvırcık yapraklı salata (Lactuca sativa L. var. crispa)'nın organik ve konvansiyonel yetişiriciliğinin verim, kalite ve toprak özelliklerine etkisi. Yüksek Lisans Tezi, Gaziosmanpaşa Üniversitesi Fen Bilimleri Enstitüsü, Tokat.

Santamaria P., 2006. Nitrate in vegetables: toxicity, content, intake and EC regulation. Journal of the Science of Food and Agriculture, 86(1): 10-17.

Smolen S., Skoczylas L., Rakoczy R., Ledwozyw-Smolen I., Kopec A., Piatkowska E., Biezanowska-Kopec R., Pysz M., Koronowicz A., Kapusta-Duch J and Sady W., 2015.
Mineral composition of field-grown lettuce (Lactuca sativa $L$.) depending on the diversified fertilization with iodine and selenium compounds. Acta Scientiarum Polonorum Hortorum Cultus, 14(6): 97-114.

Sunaryo Y., 2010. Effect of Vermicompost and Bokashi on Nutrient Content of Mustard Green and Lettuce. International Seminar on Horticulture to Support Food Security 2010 Bandar 22-23 June,Lampung - Indonesia.

Şensoy S., Abak K ve Daşgan HY., 1996. Eşdeğer Miktarda Mineral ve Organik Gübre Uygulamalarının Marulda Nitrat Birikimi, Verim ve Kaliteye Etkileri. GAP I. Sebze Tarımı Sempozyumu, 7-10 Mayıs, Şanlıurfa.

Şimşek Erşahin Y., 2007. Vermikompost ürünlerinin eldesi ve tarımsal üretimde kullanım alternatifleri. Gaziosmanpasa Universitesi Ziraat Fakultesi Dergisi, 24(2): 99-107.

Thakur M., Kumar R and Kumar S., 2016. Studies on genetic variability, correlation and path analysis in lettuce (Lactuca sativa L.) under protected conditions. Journal of Applied and Natural Science, 8(4): 1924-1930.

Topaklı Solak F., 2016. Çanakkale şartlarında tarla ve tünel altında kıvırcık salata (Lactuca sativa var. crispa) yetiştirme olanakları. Yüksek Lisans Tezi, Selçuk Üniversitesi Fen Bilimleri Enstitüsü, Konya.

TÜiK 2018. Bitkisel Üretim İstatistikleri. http://tuikapp.tuik.gov.tr/bitkiselapp/ bitkisel.zul. [Erişim: 10 Eylül 2018].

Vural H., Eşiyok D ve Duman İ., 2000. Kültür Sebzeleri (Sebze Yetiştirme). Ege Üniversitesi, Ziraat Fakültesi, Bornovaİzmir. 